Family forest land availability for the production of ecosystem services in Mississippi, United States

Edward Mutandwa ${ }^{1}$, Robert K. Grala ${ }^{2}$, Donald L. Grebner ${ }^{3}$

${ }^{1}$ Corresponding Author, Graduate Research Assistant, E-mail: em851@msstate.edu, Tel: $+16623252949,{ }^{2}$ Associate Professor, ${ }^{3}$ Professor; Box 9681, Department of Forestry, College of Forest Resources, Forest and Wildlife Research Center, Mississippi State University, Mississippi State, MS 39762-9681 


\title{
Family forest land availability for the production of ecosystem services in Mississippi, United States
}

\begin{abstract}
Forest land in the southern United States is an important source of ecosystem services. Given a predominance of family forests in the southern United States, forest management decisions of family forest owners are important in influencing the quantity and types of ecosystem services produced. The main study objective was to determine the proportion of family forest land in Mississippi that landowners would be interested in managing for the production of ecosystem services based on a mail survey of 2,025 landowners. Approximately, $64 \%$ of landowners were interested in managing their forest land for ecosystem services indicating a potential for increasing the production of these services in Mississippi. Weighted least squares (WLS) regression results indicated that importance of personal recreation ownership goal, percentage of forest land area under bottomland hardwoods, percentage of forest land area under natural mixed forests, and past participation in conservation programs were positively associated with the proportion of forest area that landowners were interested in managing for ecosystem services $(p<0.05)$. Future programs should reflect the needs of different landowner socioeconomic groups and incorporate their forest ownership objectives to increase the production of ecosystem services.
\end{abstract}

Keywords: landowner interest, mail survey, southern United States, weighted least squares 


\subsection{Introduction}

Southern forests occupy 33\% (105 million ha) of the total forest land area in the United States (Oswalt et al., 2014) and are an important source of marketable and nonmarketable ecosystem services (Shugart et al., 2003). The importance of forests in terms of nonmarketable ecosystem services has been increasing over time due to a rising demand for these services globally, nationally, and regionally (Grado et al., 2011). For example, in 2012 the volume of carbon offsets demanded by private entities at the global level covered about 26.5 million ha of forest land, representing a 4\% increase from 2011 (Peters-Stanley and Yin, 2013). The total economic value of global carbon offsets is estimated to reach more than $\$ 2$ billion by 2020 (Peters-Stanley and Yin, 2013). At the national level, a total of 77 million individuals over 16 years old participated in wildlife-related recreation such as hunting, angling, and wildlife watching in 1996 (US Census Bureau, 1996). In 2011, the number of individuals involved in the same recreational activities increased to 90 million, indicating a 17\% increase between 1996 and 2011 (Hussain et al., 2012, US Census Bureau, 2011).

A similar trend has been observed in the southern United States where the total expenditures associated with recreational activities amounted to $\$ 8.4$ billion in 2006 and $\$ 38$ billion in 2011 (Hussain et al., 2012). In Mississippi, the total economic impact of recreational activities amounted to $\$ 2.7$ billion in 2010 (Henderson et al., 2010). Waterfowl hunting alone was estimated at \$27 million in 2001 and it increased to \$86 million in 2011 (Grado et al., 2011). Given that $59 \%$ of the forest land in the southern United States is owned by family forest landowners (Measells et al., 2005, Butler and Leatherberry, 2004), the availability of family forest land dedicated to ecosystem service management is crucial for sustaining a growing demand for ecosystem services (Jack et al., 2008). 
Family forest landowners are motivated by diverse ownership goals such as timber production, wildlife habitat, recreation, aesthetics, and providing a legacy for future generations (Grebner et al., 2013, Joshi et al., 2013, Gruchy et al., 2012, Arano et al., 2004). These multiple objectives have important implications on implemented forest management regimes and types of ecosystem services produced (Kendra and Hull, 2005). For example, landowners who manage their forest land primarily for timber may be able to simultaneously produce various ecosystem services (Grebner et al., 2013). However, the level of their production might not reflect full forest potential because ecosystem services might compete with timber production (Grebner et al., 2013). On the other hand, landowners who place a high value on personal recreation may emphasize managing their forest land for wildlife habitat and aesthetics, and might be willing to implement less intensive timber harvesting prescriptions and forgo part of potential timber income (Grado et al., 2011). A better understanding of landowner forest management intentions is important for determining the forest land area that can potentially be committed to ecosystem services management (Kilgore et al., 2007).

There is evidence suggesting that private forest land area in the southern United States will decrease by $6 \%$ over the next 35 years due to population growth, forest fragmentation, and urbanization (Rozance and Rabotyagov, 2014, Feng et al., 2013). Declining forest land area will most likely have a negative impact on the production of ecosystem services (Ahn et al., 2000). A decline in the supply of ecosystem services is further exacerbated by the fact that many ecosystem services are nonmarketable and family forest landowners often do not have an incentive to actively manage their forests for these services because of potentially increased management costs, lower timber revenues, and lack of financial compensation (Hussain et al., 2007, Mozumdar et al., 2007, Richard and Stokes, 2004). 
Early work on land allocation to various economic activities can be traced back to Johann Heinrich von Thunen and David Ricardo's land rent models (Hardie et al., 2000). In these models, landowners were viewed as rational economic agents whose land use decisions were mainly driven by profit from existing land use alternatives (Lubowski et al., 2008). Various types of models based on land-use planning have also been used in contemporary land allocation research (Hagoort et al., 2008, Soghnen and Brown, 2006, Verburg et al., 2004). For instance, Verburg et al. (2004) modelled land allocation as a function of biophysical (e.g., soil fertility) and socioeconomic (e.g., market related factors) attributes, whereas Matthews et al. (2008) used agent-based modelling which recognized that the decision-making process was complex and influenced by social, environmental, and economic factors. Research related to forest management and forest landownership goals suggested that landowners consider both economic and non-economic factors in their land-use decisions related to ecosystem services (Joshi and Arano, 2009). Numerous aspects ranging from land productivity (e.g., site index, forest rent) to landowner socioeconomic characteristics (e.g., gender, education, household income) were reported as important factors affecting landowner willingness to manage their forests for ecosystem service production (Lubowski et al., 2008, Lambert et al. 2007, Nagubadi and Zhang, 2005). A better understanding of factors influencing land-use decisions of family forest landowners will help develop more effective strategies for increasing production of multiple ecosystem services from family forest lands.

Several research studies showed mixed results for factors such as gender, education, household income, property taxes, and population density in terms of their effect on forest land allocated for the production of ecosystem services (Meng and Zhang, 2013, Chen et al., 2012, Sullivan et al., 2005). However, while many previous studies analyzed forest land availability for 
ecosystem services production, they did not determine the proportion of family forest land that can be managed for ecosystem services in the future and what forest ecosystem types might be allocated to ecosystem service production. The relative proportion of forest land and types of forest ecosystems influence the quantity and range of ecosystem services that can potentially be available in the future (Jack et al., 2008, Ahn et al., 2002). Knowledge of these ecosystem service production parameters will be helpful in identifying forest areas suitable for active ecosystem service management and to quantify available ecosystem services.

The goal of this study was to determine the proportion of family forest land potentially available for the production of multiple ecosystem services across different forest types in Mississippi. Ten ecosystem services including timber, aesthetics, carbon sequestration, clean water, clean air, wildlife habitat, watershed management, ecotourism, hunting, and woody biomass production for bioenergy were considered in the study. These services are commonly found in the southern United States (USDA Forest Service, 2009). The study also examined the association of selected landowner socioeconomic factors with the proportion of forest land that landowners were interested in managing for ecosystem services. Information on the proportion of forest land and forest ecosystem types landowners are interested in managing for ecosystem services will help guide future land use planning decisions and coordinate conservation efforts not only in the southern United States but also in other World's regions encompassing substantial areas of privately owned forests. 


\section{Methods}

\subsection{Study area}

This research was conducted in Mississippi, located in the southern United States, where most of the major economic sectors include agriculture and forestry (USDA Forest Service, 2009). Approximately $65 \%$ of Mississippi's land area (8 million ha) is forested (Londo and Auel, 2004) and family forest landowners own approximately $70 \%$ of the total forest land area (Arano et al. 2004). The main forest types in Mississippi include hardwood and oak-pine forests (53\%), pine forests (33\%), and other forests (14\%) (Southeast Mississippi Forest Inventory Report, 2006). Previous studies indicated that forestry made a substantial contribution to Mississippi's economy; although, it decreased from $\$ 17.0$ billion in 2008 to $\$ 10.4$ billion in 2010 (Dahal et al., 2013, Henderson and Munn, 2013). Forests in Mississippi provide numerous ecosystem services, many of which have an increasing impact on the state economy. For example, Grado et al. (2011) indicated that the economic impact of waterfowl hunting in Mississippi amounted to $\$ 87$ million in 2011, whereas Henderson et al. (2010) reported a total state-wide economic impact of most recreational activities at $\$ 2.7$ billion in 2010 .

\subsection{Data collection}

We collected data via a survey questionnaire mailed to 2,025 randomly selected family forest landowners who had a minimum land holding of 16.2 ha (40 acres). We obtained landowner mailing addresses from commercial providers who identified landowners based on county tax records. These landowners were distributed across the state and were selected because they had a high probability for actively managing their forests (Joshi and Mehmood, 2011). Our survey implementation followed the Tailored Design Method (Dillman, 2011) in which landowners were contacted five times by an introductory letter describing the study, a letter with 
a questionnaire, a thank you/reminder postcard, and two follow-up letters with questionnaires. The survey design involved five contacts to ensure an increased landowner participation. However, it is possible that in some cases a questionnaire was completed by a person different from an addressee such as a spouse or other family member. Faculty and Extension personnel in the Department of Forestry at Mississippi State University assisted with questionnaire calibration. The questionnaire had five sections which included a description of selected ecosystems services and questions related to forest ownership goals, experience with ecosystem services and associated programs, hypothetical ecosystem service valuation scenario, and landowner socioeconomic characteristics.

\subsubsection{Data analysis}

We conducted a test to identify a potential non-response bias by comparing socioeconomic factors including gender of the landowner, household income, total forest land area owned, possession of a written forest management plan, and membership in professional, agricultural, and environmental organizations. The comparison involved the first and last 30 forest landowners who returned their questionnaires following a protocol described by Armstrong and Overton (1977) who suggested using approximately 10\% of responses in each group. We also validated the sample by using descriptive statistics from the National Woodland Owner Survey (NWOS) conducted by the USDA Forest Service in 2006 (Butler, 2008).

We performed an exploratory analysis by calculating means for variables measured on a continuous scale such as total area of forest land owned, forest land area under specific forest types, forest area which landowners were interested in managing for ecosystem services, 
household income, and landowner age. However, we used frequencies to summarize categorical variables such as gender, education, and membership in associations and organizations.

\subsubsection{Model}

We constructed a multiple regression model to quantify the relationship between landowner and forest land characteristics, and the proportion of forest land that landowners would be interested in managing for ecosystem services. Our initial selection of the model was based on the fact that the dependent variable was continuous in nature (Wooldridge, 2010). The initial model was founded on the following survey question:

"Please report the following: 1) how many acres you own by forest type and 2) how many acres you would be interested in managing for ecosystem services."

Following Gujarati and Porter (2009), we specified the initial model as follows:

$$
y_{i}=\beta_{0}+\beta_{1} x_{1 i}+\beta_{2} x_{2 i}+\beta_{3} x_{3 i}+\ldots+\beta_{n} x_{n i}+\varepsilon_{i}
$$

where $y_{i}$ represents the percentage proportion of forest land area that landowners were interested in managing for ecosystem services (quantified by dividing total forest area landowners were interested in managing for ecosystem services by total forest land area owned and expressing it as a percentage); $x_{i}$ represents a set of independent variables including landowner gender, age, education, percentage forest land area under planted pine, percentage forest land area under natural pine, percentage forest land area under bottomland hardwoods, percentage forest land area under natural mixed forests, household income, past participation in conservation programs, participation in organizations (i.e., professional, environmental, agricultural), landownership goals (i.e., providing legacy to heirs, long-term investment, personal recreation), and familiarity 
with ecosystem services (Table 1); $\varepsilon$ is the error term; and $n$ represents the number of independent variables in the model for the $i^{\text {th }}$ landowner.

We described continuous and categorical variables selected for the initial multiple regression model in Table 1 and described in this table how Likert scale data was recoded into binary variables. While there is considerable disagreement regarding the dichotomization of Likert scale and Likert-type data in literature (MacCallum et al., 2002, Knapp 1990), we used this approach for several independent variables including FAM INDEX,P.RECR, INVEST, and LEGACY and to simplify our statistical analysis (Norman, 2010). Boone and Boone (2012) suggested that Likert scale data (e.g. familiarity with ecosystem services) can be summarized using measures of central tendency such as the mean. Following Schutz and Rucker (1975) who argued that the number of Likert scale categories does not affect result quality, we eliminated "unsure" category to identify divergent opinion groups regarding Likert scale variables. Due to the fact that variable "familiarity with ecosystem services" was a composite of 10 questions measured on Likert scale, we considered it as an interval scale variable and, therefore, used the mean score as a threshold value to create a binary variable (Boone and Boone, 2012).

We subjected the initial regression model to tests of normality, heteroscedasticity, and multicollinearity to ensure that model coefficients were precisely estimated (Wooldridge, 2010). First, the Kolmogorov-Smirnov test was used to determine if the error term was normally distributed (Gujarati and Porter, 2009), whereas the White's test was used to determine if heteroscedasticity was present in the initial model (Wooldridge, 2010). Next, we implemented a $\log$ transformation of the dependent variable to normalize the error term, reduce the heterogeneity of variance, and to construct a non-linear functional form of the model (Gujarati 
and Porter, 2009). A log transformation of the dependent variable is often prescribed in situations characterized by non-constancy of error variance (Kutner et al., 2005).

To determine if the developed log-level regression model was appropriately specified, we conducted the Ramsey RESET test (Pevalin and Robson, 2009). Multicollinearity diagnostic tests were conducted using the variance inflation factor (VIF) with a threshold value of 10 indicating absence of multicollinearity (Wooldridge, 2010). The multicollinearity tests were necessary because presence of multicollinearity may affect precision of parameter estimates through an increase in error variance (Gujarati and Porter, 2009). We used the White's test to determine whether heteroscedasticity had been removed from the model after log transformation. Further, we selected Weighted Least Squares (WLS) regression to reduce the effect of the remaining dependent variable ( $y$ ) outlier cases which were identified through DFBETA values (Kutner et al., 2005). The formula $(2 / \sqrt{ } \mathrm{n})$ was used to calculate the minimum DFBETA value beyond which there would be an effect on the precision of the parameter estimates. We also used WLS to reduce the effect of a possible bias in parameter estimates that could have been introduced by a censored dependent variable (Khan and Shaw, 2013, Bao et al., 2007).

We specified the final regression model based on WLS as follows:

$$
\ln \left(y_{i}\right)=\beta_{0}+\beta_{1} x_{1 i}+\beta_{2} x_{2 i}+\beta_{3} x_{3 i}+\ldots+\beta_{n} x_{n i}+\varepsilon_{i}
$$

where $\ln \left(y_{i}\right)$ is a $\log$ transformed dependent variable representing the proportion of forest land area that landowners were interested in managing for ecosystem services (quantified by dividing a total forest land area landowners were interested in managing for ecosystem services by total forest land area owned and expressing it as percentage); $x_{i}$ represents a set of independent variables including landowner gender, age, education, percentage forest land area under planted pine, percentage forest land area under natural pine, percentage forest land area under 
bottomland hardwoods, percentage forest land area under natural mixed forests, household income, past participation in conservation programs, participation in organizations (i.e., professional, environmental, agricultural), landownership goals (i.e., providing legacy to heirs, long-term investment, personal recreation), familiarity with ecosystem services, and $\varepsilon$ is the error term.

In terms of interpretation of regression coefficients for binary variables, we interpreted them using $100[\exp (\beta-1 / 2 \times v(\beta))-1]$, where $\beta$ is the regression coefficient of the binary variable and $\mathrm{v}(\beta)$ is the variance of $\beta$ (Kennedy 1981). We also expressed the statistical association of a binary independent variable with the dependent variable in percentage terms as $100[\exp (\beta-$ $1 / 2 \times v(\beta))-1]$ (Jan van Garderen and Shah 2002).

\section{Results}

\subsubsection{Landowner socioeconomic characteristics}

The mail survey had a response rate of $37.1 \%$. A non-response bias test indicated no significant differences between the first and last 30 respondents for variables included in the test: size of forest land owned $(\mathrm{t}=1.17, p=0.247)$, gender $(\mathrm{t}=0.907, p=0.368)$, annual household income $(\mathrm{t}=0.588, p=0.559)$, possession of a forest management plan $(\mathrm{t}=0.041, p=0.967)$, membership in environmental organizations $(\mathrm{t}=0.033, p=0.967)$, membership in agricultural organizations $(\mathrm{t}=0.498, p=0.620)$, and membership in professional organizations $(\mathrm{t}=0.768$, $p=0.445$ ). Our sample was dominated by male landowners who constituted $78.0 \%$ of respondents, whereas $22.0 \%$ were female landowners. In general, $72 \%$ of landowners were above 60 years in age with an average of 65 years for male and 68 years for female landowners $(p<0.05)$. While about half of the sampled landowners had at least a college degree, an almost 
equal percentage of landowners had a high school education or less. There was a statistical relationship between age and education level where older landowners (73 years and above) completed a high school education or less and younger landowners (64 years or less) had at least a Bachelor's degree $\left(\chi^{2}=1.448, p<0.01\right)$. Our sample estimates related to gender, age, education, income, and area of forest land owned were consistent with estimates reported in NWOS for Mississippi (Table 2).

In terms of membership, $11 \%$ were members of County Forest Associations (CFAs), 9\% belonged to Mississippi Forest Association (MFA), and 26\% indicated they were members of other professional organizations. About $50 \%$ of the landowners had a 2011 gross household income between $\$ 30,000$ and $\$ 100,000$. We provided summary statistics for socioeconomic and forest land data in Table 3.

\subsubsection{Forest land characteristics}

The mean size of the forest land owned by landowners in Mississippi was 101 ha and mainly included pine plantations, bottomland hardwoods, and mixed pine-hardwood stands. On average, landowners stated they were interested in managing 64.7 ha $(64.3 \%)$ of their forest land for multiple ecosystem services. Not all forest types were found on each forest property resulting in a discrepancy between the total forest land area owned and total area of individual forest types summed together. In terms of forest types, landowners were willing to manage for ecosystem services 33.6 ha of pine plantations, 24.9 ha of bottomland hardwoods, 20.0 ha of mixed pinehardwood stands, 17.5 ha of natural hardwoods, and 13.7 ha of natural pine stands. This equates to $31.6 \%$ of reported pine plantation, $29.7 \%$ of natural mixed pine-hardwood, $28.1 \%$ of natural hardwood, $13.9 \%$ of bottomland hardwood, and $12.4 \%$ for natural pine forest land area. 
Landowners prioritized long-term investment, legacy, and personal recreation as the main forest land ownership goals. In addition, more than half of the sampled landowners (57\%) were highly familiar with ecosystem services (Table 3). An average area for each forest type and the corresponding forest land area that landowners were interested in managing for ecosystem services are presented in Table 4 .

\subsection{Association of socioeconomic factors with forest land area landowners were willing to manage for ecosystem services}

An initial multiple regression model was heteroscedastic with the error term not normally distributed and, thus, it required transformation. A log transformation of the dependent variable eliminated heterogeneity of variance as indicated by the White's test $(\mathrm{F}=52.49, p=0.77)$. The loglevel regression model also satisfied the normality assumption with a Kolmogorov-Smirnov value of 0.96 ( $p=0.07)$. In addition, Ramsey Reset test results suggested that specification bias was not present in the log-level regression model $(\mathrm{F}=41.99, p=0.42)$. VIF values for each independent variable were less than 10 indicating that multicollinearity was also not present.

Several DFBETA values for regression coefficients were greater than 0.078 indicating outlying dependent variable (y) cases. To correct this situation, we used a weighted least squares model and estimation results are reported in Table 5. The pattern of variance suggested the use of the sample variance inverse $\left(1 / \mathrm{s}^{2}\right)$ as a weight for WLS regression (Kutner et al. 2005).

Heteroscedasticity was not present in the WLS regression model as reflected by the White's test $\left(\chi^{2}=52.49, p=0.77\right)$. The WLS regression model had five independent variables that were statistically related with the proportion of forest land available for producing multiple ecosystem services. Personal recreation goal $(p<0.05)$, past enrolment in a conservation program $(p<0.10)$, percentage forest land area under bottomland hardwoods $(p<0.10)$, and percentage forest land area under natural mixed pine forests $(p<0.10)$ were associated with an increased percentage 
proportion of forest land that landowners were interested in managing for ecosystem services. However, possession of a written forest management plan was associated with a decreased percentage proportion of forest land that landowners stated were interested in managing for ecosystem services $(p<0.05)$.

A one percent increase in the proportion of area under bottomland hardwoods was associated with a $0.9 \%$ increase in the proportion of forest land that landowners were interested in managing for ecosystem services. Landowners who previously participated in conservation programs were interested in managing $45 \%$ more forest land for ecosystem services than nonparticipating landowners. In contrast, landowners who possessed a written forest management plan were interested in managing $43 \%$ less of forest land for ecosystem services than landowners who did not have a plan.

\section{Discussion}

Mississippi has a potential for providing multiple ecosystem services from private family forest lands because $64 \%$ of forest land can potentially be allocated for this purpose. However, the largest allocation of family forest land was most likely in terms of bottomland hardwoods, pine, and natural mixed pine-hardwood forests indicating a varying capacity and different management prescriptions needed to achieve a desired level of ecosystem services. For example, mixed bottomland hardwoods and natural pine-hardwood forests might provide a variety of ecosystem services such as wildlife habitat, hunting, fishing, clean air and water, and soil erosion control (Ribe, 1989). However, mixed stands also might require more complex management prescriptions based on longer rotations, lower thinning intensities and partial cutting necessary to create a diverse forest for a variety of wildlife species (Lockhart et al., 2006). In contrast, 
loblolly pine (Pinus taeda) plantations, which are less diverse and require less complex management prescriptions, are also likely to provide less diverse ecosystem services (Raunikar and Buongiorno, 2006). Forest management prescriptions for less diverse stands may include tree release, pre-commercial thinning, and clear cutting activities (Grebner et al., 2013). However, loblolly pine stands might be more suitable for particular ecosystem services such as carbon sequestration or biomass production for bioenergy purposes. In addition, ongoing efforts to re-establish longleaf pine (Pinus palustris) to its natural range in the southern United States might lead to more diverse pine forest ecosystems and a wider range of ecosystem services produced from pine forests (Mitchell et al., 2006).

Our results related to personal recreation showed that landowners who considered it as an important ownership goal were more likely to actively manage their forests for multiple ecosystem services. This finding is in line with previous studies conducted in the southern United States (Munn et al., 2010, Joshi and Arano, 2009, Gunter et al., 2001) which reported that landowners with a greater preference for recreational opportunities were more likely to manage forests for multiple ecosystem services to enhance their landownership goals. An increasing demand for recreational activities in the southern United States may be attributed to the strong connection between the society and forests as well as appreciation for the natural environment (Cordell and Tarrant, 2002). The implication of this finding is that in addition to already existing programs, it is important to develop approaches to encourage such landowners to actively manage their forests. Such approaches might involve community peers who may encourage other landowners towards forest management geared for multiple forest outputs (Hughes et al., 2005). In addition, various communication tools that can be used that include magazines, newsletters, and online extension applications (Hughes et al., 2005). Landowner forest management decisions 
will have a greater impact on the provision of ecosystem services in the future; thus, it is necessary to emphasize outreach activities designed specifically for landowners interested in recreational aspects of forest ownership (Kueper et al., 2014, Hughes et al., 2005, Warren, 2003).

Regarding ownership of a written forest management plan, our expectation was that possession of a plan will improve landowner knowledge of, and access to, relevant information about ecosystem services and available monetary incentives, and thus increase landowner interest in managing their forests for ecosystem services (Arano et al., 2004). However, results indicated that landowners with forest management plans were likely to manage less forest land for multiple ecosystem services. This result was not consistent with the majority of other studies which reported that possession of a forest management plan was positively related to land allocation for ecosystem services (Creamer et al., 2012, Sullivan et al., 2005, Joshi and Arano, 2009, Gunter et al., 2001). One potential explanation is that landowners who had forest management plans might already have committed their land to other ecosystem services or other outputs such as timber (Joshi and Arano, 2009, Arano et al., 2004). Thus, it is essential to demonstrate how management for additional ecosystem services may help better attain their ownership goals by modifying their current forest management activities (Kilgore et al., 2007). Furthermore, these landowners may benefit from information showing how such forest management practices will enhance the value of their property in the long term (Jenkins et al., 2010). However, landowners who did not have written management plans should also be included in outreach efforts to assist them in formalizing their ownership objectives and encourage them to actively manage their forests for ecosystem services production (Kluender and Walkingstick, 2000). 
The analysis also showed that previous participation in conservation programs had a positive association with the proportion of forest land that landowners were interested in managing for ecosystem services. Landowners who participated in previous conservation programs can be encouraged to share their experience and information on relevant conservation programs with other landowners and serve as leaders in their communities helping increase the use of best forest management practices facilitating ecosystem services (Cason et al., 2006). The use of landowner leaders might be an effective tool in promoting sustainable forestry because a large number of landowners are not actively involved in professional networks and organizations (Rickenbach, 2009, Butler, 2008). For example, in Mississippi formal training programs from public forestry Extension reaches less than $2 \%$ of landowners, indicating the need for a wide range of strategies for outreach activities (Hughes et al., 2005).

\section{Conclusions and policy implications}

There is a substantial potential for increasing a production of ecosystem services in Mississippi as approximately $64 \%$ of NIPF landowners were interested in managing their forests for this purpose. However, forest land area potentially available for ecosystem service management varied across landowner socioeconomic characteristics, their ownership goals, and forest types. Most landowners were willing to manage bottomland hardwood, pine, and natural mixed pine-hardwood forests for the provision of multiple ecosystem services. In addition, landowner interest in managing forests for ecosystem services was significantly associated with personal recreation goal and past enrolment in a conservation program. Although manipulation and management of private forest land for recreational activities such as hunting and fishing by landowners may be desirable, it is also associated with different establishment and intermediate costs. Such costs might disincentivize landowners from implementing needed forest management 
strategies and might ultimately result in a reduction of land area allocated for recreational purposes. Existing and future federal conservation programs such as the Conservation Reserve Program should, therefore, play a crucial role in providing landowners with diverse opportunities for reducing costs associated with such activities. The presence of alternative channels of financial assistance through public and private programs is likely to enhance landowner willingness to devote more forest land for multiple ecosystem services. Therefore, outreach efforts focusing on specific landowner socioeconomic groups and reflecting their specific needs and forest ownership objectives will be needed to increase landowner engagement in forest management activities facilitating increased production of ecosystem services. While some landowners who already manage their forests for ecosystem services might benefit from technical assistance, other landowners, such as those with investment-oriented ownership objectives, might require monetary compensation or cost-share. Information on the relationship between landowner socioeconomic characteristics and their interest in managing forest land for ecosystem services will be helpful in developing more effective outreach and conservation programs. When combined with specific forest types, it will be helpful not only in determining the total forest land area available for ecosystem service production but also in identifying priority areas suitable for individual ecosystem services such as habitat for endangered species. While our analysis examined landowner interest in managing a forest land for ecosystem services, it did not include market factors such prices of commercial wood products, land value, interest rates, and taxes as well as format of ecosystem service programs and agreements. These factors can affect landowner forest management decisions and consequently forest land area available for dedicated production of ecosystem services. 


\section{Acknowledgements}

This research was funded by the Natural Resource Enterprises Program, Forest and Wildlife

Research Center, Mississippi State University and approved as a publication FO__. This material is based upon work that is supported by the National Institute of Food and Agriculture, U.S. Department of Agriculture, MISZ-061180 under 222774. 


\section{References}

Ahn, S., Plantinga, A.J., Alig, R.J., 2000. Predicting future forestland area: A comparison of econometric approaches. For. Sci. 46(3), 363-376.

Ahn, S., Plantinga, A.J., Alig, R.J., 2002. Determinants and projections of land use in the South Central United States. South. J. Appl. For. 26(2), 78-84.

Arano, K.G., Munn, I.A., Gunter, J.E., Bullard, S.H., Doolittle, M.L., 2004. Modeling landowner participation in a proposed reforestation loan program. Small-scale For. Econ. Manage. Policy. 3(2), 177-190.

Armstrong, J.S., Overton, T., 1977. Estimating nonresponse bias in mail surveys. J. Mark. Res. 14, 396-402.

Bao, Y., He, S., Mei, C., 2007. The Koul-Susarla-Van Ryzin and weighted least squares estimates for censored linear regression model: A comparative study. Comput. Stat. Data An., 51(12), 6488-6497.

Boone, H.N., Boone, D.A., 2012. Analyzing Likert data. J. Extens. 50(2), 1-5.

Butler, B.J., Leatherberry, E.C., 2004. America's family forest owners. J. For. 102(7), 4-14.

Butler, B.J., 2008. Family Forest Owners of the United States, 2006. Gen. Tech. Rep. NRS-27. Newtown Square, PA: U.S. Department of Agriculture, Forest Service, Northern Research Station. 72 p. Accessed on 15 September 2015 from http://www.nrs.fs.fed.us/pubs/gtr/gtr_nrs27.pdf.

Cason, J.D., Grebner, D.L., Londo, A.J., Grado, S.C., 2006. Potential for carbon storage and technology transfer in the southeastern United States. J. Extens. 44(4). 4FEA6. Accessed on 13 September 2014 from http://www.joe.org/joe/2006august/a6p.shtml.

Chen, X., Lupi, F., An, L., Sheely, R., Vina, A., Liu, J., 2012. Agent-based modeling of the effects of social norms on enrollment in payments for ecosystem services. Ecol. Model. $229,16-24$.

Cordell, H.K., Tarrant, M.A., 2002. Southern forest resource assessment highlights: changing demographics, values, and attitudes. J. For. 100(7), 28-33.

Creamer, S.F., Blatner, K.A., Butler, B.J., 2012. Certification of family forests: What influences owners' awareness and participation? J. Forest. Econ. 18(2), 131-144.

Dahal, R.P., Munn, I.A., Henderson, J.E., 2013. Economic Impacts of the Forest Products Industry in the South (2009). In 2013 Annual Meeting, February 2-5, 2013, Orlando, Florida (No. 142562). Southern Agricultural Economics Association. Accessed on 5 June 2015 from http://www.geconsearch. umn.edu/bitstream/142562/2/Dahal_2013. 
Dillman, D.A., 2011. Mail and Internet surveys: The tailored design method-2007 Update with new Internet, visual, and mixed-mode guide, third ed. John Wiley \& Sons, New York, NY, USA.

Feng, H., Hennessy, D.A., Miao, R., 2013. The effects of government payments on cropland acreage, Conservation Reserve Program enrollment, and grassland conversion in the Dakotas. Am. J. Agr. Econ. 95(2), 412-418.

Grado, S.C., Hunt, K.M., Hutt, C.P., Santos, X.T., Kaminski, R.M., 2011. Economic impacts of waterfowl hunting in Mississippi derived from a state-based mail survey. Hum. Dimens. Wildl. 16(2), 100-113.

Grebner, D.L., Bettinger, P., Siry, J.P., 2013. Introduction to forestry and natural resources. Academic Press, MA, USA.

Gruchy, S.R., Grebner, D.L., Munn, I.A., Joshi, O., Hussain, A., 2012. An assessment of nonindustrial private forest landowner willingness to harvest woody biomass in support of bioenergy production in Mississippi: A contingent rating approach. Forest. Policy. Econ. 15, 140-145.

Gujarati, D.N., Porter, D.C., 2009. Basic econometrics, fifth ed. The McGraw-Hill, New York, USA.

Gunter, J.E., Bullard, S.H., Doolittle, M.L., Arano, K.G., 2001. Reforestation of Harvested Timberlands in Mississippi: Behavior and Attitudes of Nonindustrial Private Forest Landowners. Forest and Wildlife Research Center, Research Bulletin FO172, Mississippi State University.

Hagoort, M., Geertman, S., Ottens, H., 2008. Spatial externalities, neighbourhood rules and CA land-use modelling. Ann Reg Sci. 42(1), 39-56.

Hardie, I., Parks, P., Gottleib, P., Wear, D., 2000. Responsiveness of rural and urban land uses to land rent determinants in the US South. Land Econ. 76(4), 659-673.

Henderson, J.E., Grado, S.C., Munn, I.A., Jones, W.D., 2010. Economic Impacts of Wildlifeand Fisheries Associated Recreation on the Mississippi Economy: An Input-Output Analysis. Forest and Wildlife Research Center, Research Bulletin FO 429 Mississippi State University, MS. 21pp.

Henderson, J.E., Munn, I.A., 2013. Economic Importance of Forestry and Forest Products to Mississippi Counties: A Publication Series to Help the Forestry Community Educate Local Government Officials and the Public. J. For. 111(6), 388-394.

Hughes, G., Measells, M.K., Grado, S.C., Dunn, M.A., Idassi, J.O., Zielinske, R.J., 2005. Underserved forest landowner workshops: Opportunities for landowners and Extension. J. Extens. 43(4), 4FEA5. 
Hussain, A., Munn, I.A., Grado, S.C., West, B.C., Daryl Jones, W.D., Jones, J.C., 2007. Hedonic analysis of hunting lease revenue and landowner willingness to provide fee-access hunting. For. Sci, 53(4), 493-506.

Hussain, A., Munn, I.A., Holland, D.W., Armstrong, J.B., Spurlock, S.R., 2012. Economic Impact of Wildlife-Associated Recreation Expenditures in the Southeast United States: A General Equilibrium Analysis. J. Agr. Appl. Econ. 44(1), 63.

Jack, B.K., Kousky, C., Sims, K.R., 2008. Designing payments for ecosystem services: Lessons from previous experience with incentive-based mechanisms. Proc. Natl. Acad. Sci. U.S.A. 105(28), 9465-9470.

Jan van Garderen, K., Shah, C., 2002. Exact interpretation of dummy variables in semilogarithmic equations. Econom. J. 5(1), 149-159.

Jenkins, W.A., Murray, B.C., Kramer, R.A., Faulkner, S.P., 2010. Valuing ecosystem services from wetlands restoration in the Mississippi Alluvial Valley. Ecol. Econ. 69(5), 10511061.

Joshi, S., Arano, K.G., 2009. Determinants of private forest management decisions: a study on West Virginia NIPF landowners. Forest. Policy. Econ. 11(2), 118-125.

Joshi, O., Grebner, D.L., Munn, I.A., Hussain, A., Gruchy, S.R., 2013. Understanding Landowner Preferences for Woody Biomass Harvesting: A Choice Experiment-Based Approach. For. Sci. 59(5), 549-558.

Joshi, O., Mehmood, S.R., 2011. Factors affecting nonindustrial private forest landowners' willingness to supply woody biomass for bioenergy. Biomass. Bioenerg. 35(1), 186-192.

Khan, M.H.R., Shaw, J.E.H., 2013. On dealing with censored largest observations under weighted least squares. arXiv preprint arXiv:1312.2533.

Kendra, A., Hull, R.B., 2005. Motivations and behaviors of new forest owners in Virginia. For. Sci 51(2), 142-154.

Kennedy, P.E., 1981. Estimation with correctly interpreted dummy variables in semilogarithmic equations [the interpretation of dummy variables in semilogarithmic equations]. Am. Econ. Rev. 71(4), 801.

Kilgore, M.A., Greene, J.L., Jacobson, M.G., Straka, T.J., Daniels, S.E., 2007. The influence of financial incentive programs in promoting sustainable forestry on the nation's family forests. J. For. 105(4), 184-191.

Kluender, R.A., Walkingstick, T.L., 2000. Rethinking how nonindustrial landowners view their lands. South. J. Appl. For. 24(3), 150-158.

Knapp, T.R., 1990. Treating ordinal scales as interval scales: An attempt to resolve the controversy. Nurs. Res. 39, 121-123. 
Kueper, A.M., Sagor, E.S., Blinn, C.R., Becker, D.R., 2014. Extension Forestry in the United States: Master volunteer and other peer-learning programs. J. For. 112(1), 23-31.

Kutner, M.H., Nachtsheim, C.J., Neter, J., Li, W., 2005. Applied linear statistical models, fifth ed. McGraw-Hill Irwin, New York, NY, USA.

Lambert, D.M., Sullivan, P., Claassen, R., Foreman, L., 2007. Profiles of US farm households adopting conservation-compatible practices. Land Use Policy. 24(1), 72-88.

Lockhart, B.R., Ezell, A.W., Hodges, J.D., Clatterbuck, W.K., 2006. Using natural stand development patterns in artificial mixtures: A case study with cherrybark oak and sweetgum in east-central Mississippi, USA. Forest Ecol Manag. 222(1), 202-210.

Londo, A.J., Auel, J.B., 2004. An assessment of Mississippi's nonindustrial private forest landowners' knowledge of forestry best management practices. Pages 99-102 in K.F. Connor, editor. Proceedings of the 12th Biennial Southern Silvicultural Research Conference. Gen. Tech. Rep SRS-71. Asheville, NC: U.S. Department of Agriculture, Forest Service, Southern Research Station. 594 p. Accessed on 13 February 2015 from http://www.srs.fs.usda.gov/ pubs/ viewpub.php?index $=6615$.

Lubowski, R.N., Plantinga, A.J., Stavins, R.N., 2008. What drives land-use change in the United States? A national analysis of landowner decisions. Land Econ. 84(4), 529-550.

MacCallum, R.C., Zhang, S.B., Preacher, K.J., Rucker, D.D., 2002. On the practice of dichotomization of quantitative variables. Psychol. Methods. 7, 19-40.

Matthews, R.B., Gilbert, N.G., Roach, A., Polhill, J.G., Gotts, N.M., 2008. Agent-based land-use models: a review of applications. Landscape Ecol. 22(10), 1447-1459.

Measells, M.K., Grado, S.C., Hughes, H.G., Dunn, M.A., Idassi, J., Zielinske, B., 2005. Nonindustrial private forest landowner characteristics and use of forestry services in four southern states: results from a 2002-2003 mail survey. South. J. Appl. For. 29(4), 194199.

Meng, L., Zhang, D., 2013. Impacts of property tax on land use change decisions in Georgia. Urban Ecosyst. 16, 3-12

Mitchell, R.J., Hiers, J.K., O'Brien, J.J., Jack, S.B., Engstrom, R.T., 2006. Silviculture that sustains: the nexus between silviculture, frequent prescribed fire, and conservation of biodiversity in longleaf pine forests of the southeastern United States. Can. J. For. Res. 36(11), 2724-2736.

Mozumder, P., Meghan Starbuck, C., Berrens, R.P., Alexander, S., 2007. Lease and fee hunting on private lands in the US: A review of the economic and legal issues. Hum. Dimens. Wildl. 12(1), 1-14. 
Munn, I.A., Hussain, A., Spurlock, S., Henderson, J.E., 2010. Economic impact of fishing, hunting, and wildlife-associated recreation expenditures on the southeast US regional economy: an input-output analysis. Hum. Dimens. Wildl. 15(6), 433-449.

Nagubadi, R.V., Zhang, D., 2005. Determinants of timberland use by ownership and forest type in Alabama and Georgia. J. Agr. Appl. Econ. 37(1), 173-186.

Norman, G., 2010. Likert scales, levels of measurement and the "laws" of statistics. Adv. Health. Sci. Educ. 15(5), 625-632.

Oswalt, S.N., Smith, W.B., Miles, P.D., Pugh, S.A., 2014. Forest Resources of the United States, 2012: a technical document supporting the Forest Service 2015 update of the RPA Assessment. USDA For. Serv. Gen. Tech. Rep. WO-91. 218 pp., Washington, DC: U.S. Department of Agriculture, Forest Service, Washington Office. Accessed on 23 September 2015 from http://www.srs.fs.usda.gov/pubs/47322.

Peters-Stanley, M., Yin, D., 2013. Maneuvering the Mosaic: State of the Voluntary Carbon Markets 2013. Forest Trends Association. Accessed on 12 December 2014 from http://www.forest-trends.org/.

Pevalin, D., Robson, K., 2009. The stata survivor manual. The Open University Press. McGraw Hill, England, UK.

Raunikar, R., Buongiorno, J., 2006. Willingness to pay for forest amenities: the case of nonindustrial owners in the south central United States. Ecol. Econ. 56(1), 132-143.

Ribe, R.G., 1989. The aesthetics of forestry: what has empirical preference research taught us? Environ. Manage. 13(1), 55-74.

Richards, K.R., Stokes, C., 2004. A review of forest carbon sequestration cost studies: a dozen years of research. Clim. Chang. 63(1-2), 1-48.

Rickenbach, M., 2009. Serving members and reaching others: the performance and social networks of a landowner cooperative. Forest. Policy. Econ. 11(8), 593-599.

Rozance, M.A., Rabotyagov, S.S., 2014. Washington State small forest landowners: Who intends to develop their forestlands and when. J. For. 112(6), 572-580.

Schutz, H.G., Rucker, M.H., 1975. A comparison of variable configurations across scale lengths: An empirical study. Educ. Psychol. Meas. 35(2), 319-324.

Shugart, H.H., Sedjo, R.A., Sohngen, B.L., 2003. Forests \& global climate change: Potential impacts on US forest resources. Pew Center on Global Climate Change. Center for Climate and Energy Solutions, VA, USA.

Sohngen, B., Brown, S., 2006. The influence of conversion of forest types on carbon sequestration and other ecosystem services in the South Central United States. Ecol. Econ. 57(4), 698-708. 
Southeast Mississippi Forest Inventory Report., 2006. State of Mississippi Southeast District Forest inventory, Mississippi Institute of Forest Inventory. Accessed on 6 June 2013 fromhttp://www.mifi.ms.gov/.

Sullivan, J., Amacher, G.S., Chapman, S. 2005. Forest banking and forest landowners forgoing management rights for guaranteed financial returns. Forest. Policy. Econ. 7(3), 381-392.

USDA Forest Service., 2009. More about ecosystem services. Accessed on 13 January 2012 from http://www.fs.fed.us/ecosystemservices/About_ES/index.shtml.

U.S. Census Bureau., 1996. National Survey of Fishing, Hunting, and Wildlife-Associated Recreation.Accessed on 18 December 2014 fromhttps://www.census.gov/prod/3/97pubs/fhw96nat.pdf.

U.S. Census Bureau., 2011. National Survey of Fishing, Hunting, and Wildlife-Associated Recreation. Accessed on 18 December 2014 from https://www.census.gov/prod/2012pubs/fhw11-nat.pdf.

Verburg, P.H., Van Eck, J.R., de Nijs, T.C., Dijst, M.J., Schot, P., 2004. Determinants of landuse change patterns in the Netherlands. Environ. Plann. B. 31(1), 125-150.

Warren, S.T., 2003. One step further: Women's access to and control over farm and forest resources in the US South. S.R.S. 19(2), 94-113.

Wooldridge, J.M., 2010. Econometric analysis of cross section and panel data, fifth ed. MIT press, Cambridge, England. 
Table 1. Description of variables included in the model to quantify the proportion of forest land area that family landowners in Mississippi were interested in managing for ecosystem services based on a mail survey conducted in 2012 .

\begin{tabular}{|c|c|}
\hline Variable & Variable description \\
\hline INTEREST & $\begin{array}{l}\text { Percentage proportion of forest land area landowners were } \\
\text { interested in managing for ecosystem services. }\end{array}$ \\
\hline FAM INDEX $^{\mathrm{a}}$ & $\begin{array}{l}\text { Familiarity with ecosystems services: } 1 \text { if high familiarity, } 0 \\
\text { otherwise. }\end{array}$ \\
\hline P.RECR ${ }^{\text {b }}$ & $\begin{array}{l}\text { 1if personal recreation was an important forest land ownership } \\
\text { goal, } 0 \text { otherwise. }\end{array}$ \\
\hline INVEST $^{\mathrm{b}}$ & $\begin{array}{l}1 \text { if a long-term investment was an important forest land } \\
\text { ownership goal, } 0 \text { otherwise. }\end{array}$ \\
\hline LEGACY ${ }^{\mathrm{b}}$ & 1 if legacy for heirs was an important ownership goal, 0 otherwise. \\
\hline FMP & 1 if a landowner had a forest management plan, 0 otherwise. \\
\hline PROFORG & $\begin{array}{l}1 \text { if a landowner was a member of a professional organization, } 0 \\
\text { otherwise. }\end{array}$ \\
\hline ENVORG & $\begin{array}{l}1 \text { if a landowners was a member of an environmental organization, } \\
0 \text { otherwise. }\end{array}$ \\
\hline AGRICORG & $\begin{array}{l}1 \text { if a landowner was a member of an agricultural organization, } 0 \\
\text { otherwise. }\end{array}$ \\
\hline ENROL & $\begin{array}{l}1 \text { if forest land was previously enrolled in a conservation program, } \\
0 \text { otherwise. }\end{array}$ \\
\hline EDUC & 1 if a landowners had a Bachelor degree or higher, 0 otherwise. \\
\hline GENDER & 1 if a landowner was a male, 0 if a female. \\
\hline INC & $\begin{array}{l}\text { Gross household income in } 2011 \text { in US\$ (measured in } \\
\text { U.S.\$1,000's). }\end{array}$ \\
\hline AGE & Landowner age in years. \\
\hline P.PINE & Percentage forest land area under planted pine. \\
\hline P.NTPINE & Percentage forest land area under natural pine. \\
\hline P.BOTMLN & Percentage forest land area under bottomland hardwoods. \\
\hline P.NTMXD & Percentage forest land area under natural mixed forests. \\
\hline \multicolumn{2}{|c|}{ 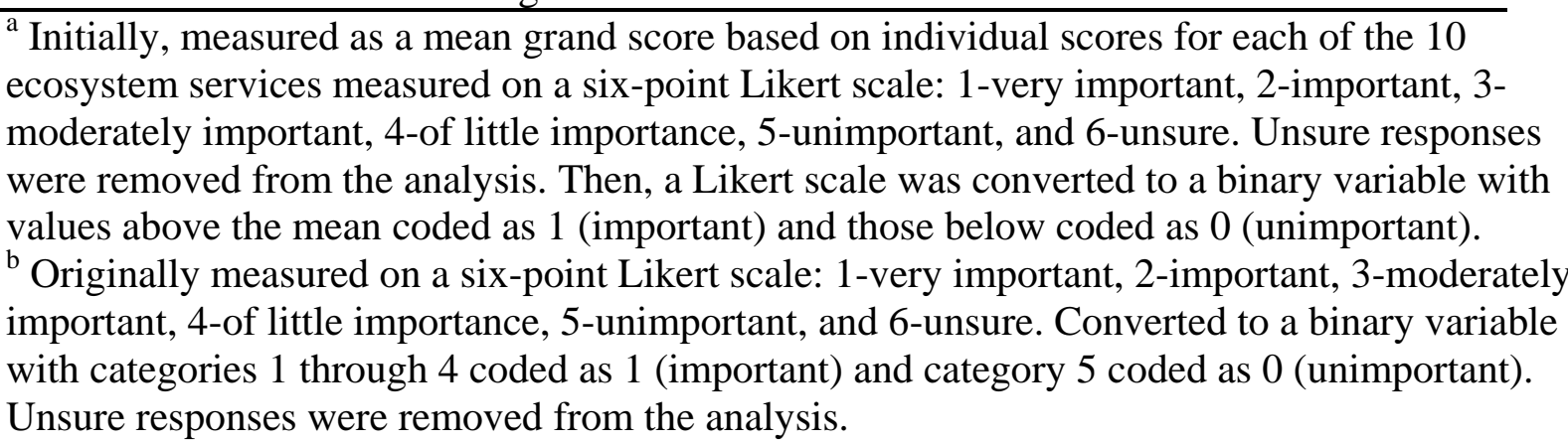 } \\
\hline
\end{tabular}


Table 2. Comparison of Mississippi's nonindustrial private landowner sample estimates obtained via a mail survey conducted in 2012 with estimates reported in the National Woodland Owner Survey (NWOS).

\begin{tabular}{lll}
\hline $\begin{array}{l}\text { Landowner socio-demographic } \\
\text { characteristics }\end{array}$ & Survey Sample & NWOS $^{1}$ \\
\hline Age (years) & 66 & $65-74$ years \\
Predominant Gender & Male & Male \\
Education & Bachelor degree & Bachelor degree \\
Income & $\$ 75,000$ & $\$ 50,000-99,999$ \\
Total land size & 100.0 ha & $40.5-202.0$ ha \\
\hline
\end{tabular}

${ }^{1}$ Source: Butler (2008) 
Table 3. Summary statistics for socioeconomic and forest land characteristics based on a mail survey of Mississippi's forest family owners conducted in 2012.

\begin{tabular}{|c|c|c|c|}
\hline Variable & Variable description & Mean & SD \\
\hline INTEREST & $\begin{array}{l}\text { Percentage proportion of forest land area landowners } \\
\text { were interested in managing for ecosystem services. }\end{array}$ & 0.64 & 0.69 \\
\hline FAM INDEX $^{\mathrm{a}}$ & $\begin{array}{l}\text { Familiarity with ecosystems services, } 1 \text { if a landowner } \\
\text { was highly familiar, } 0 \text { otherwise. }\end{array}$ & 0.57 & 0.49 \\
\hline P.RECR ${ }^{b}$ & $\begin{array}{l}\text { 1if personal recreation was an important forest land } \\
\text { ownership goal, } 0 \text { otherwise. }\end{array}$ & 0.91 & 0.27 \\
\hline INVEST $^{b}$ & $\begin{array}{l}1 \text { if a long-term investment was an important forest land } \\
\text { ownership goal, } 0 \text { otherwise. }\end{array}$ & 0.93 & 0.24 \\
\hline LEGACY $^{\mathrm{b}}$ & $\begin{array}{l}1 \text { if legacy for heirs was an important ownership goal, } 0 \\
\text { otherwise. }\end{array}$ & 0.95 & 0.21 \\
\hline FMP & $\begin{array}{l}1 \text { if a landowner had a forest management plan, } 0 \\
\text { otherwise. }\end{array}$ & 0.17 & 0.37 \\
\hline PROFORG & $\begin{array}{l}1 \text { if a landowner was a member of a professional } \\
\text { organization, } 0 \text { otherwise. }\end{array}$ & 0.26 & 0.44 \\
\hline ENVORG & $\begin{array}{l}1 \text { if a landowners was a member of an environmental } \\
\text { organization, } 0 \text { otherwise. }\end{array}$ & 0.03 & 0.18 \\
\hline AGRICORG & $\begin{array}{l}1 \text { if a landowner was a member of an agricultural } \\
\text { organization, } 0 \text { otherwise. }\end{array}$ & 0.15 & 0.35 \\
\hline ENROL & $\begin{array}{l}1 \text { if forest land was previously enrolled in a } \\
\text { conservation program, } 0 \text { otherwise. }\end{array}$ & 0.09 & 0.29 \\
\hline EDUC & $\begin{array}{l}1 \text { if a landowners had a Bachelor degree or higher, } 0 \\
\text { otherwise. }\end{array}$ & 0.53 & 0.25 \\
\hline GENDER & 1 if a landowner was a male, 0 if a female. & 0.77 & 0.41 \\
\hline INC & $\begin{array}{l}\text { Gross household income in } 2011 \text { in US\$ (measured in } \\
\text { U.S.\$1,000's). }\end{array}$ & 77.08 & 47.27 \\
\hline AGE & Landowner age in years. & 65.55 & 12.03 \\
\hline P.PINE & Percentage forest land area under planted pine. & 0.52 & 0.53 \\
\hline P.NTPINE & Percentage forest land area under natural pine. & 0.21 & 0.25 \\
\hline P.BOTMLN & $\begin{array}{l}\text { Percentage forest land area under bottomland } \\
\text { hardwoods. }\end{array}$ & 0.22 & 0.26 \\
\hline P.NTMXD & Percentage forest land area under natural mixed forests. & 0.47 & 0.39 \\
\hline
\end{tabular}


Table 4. Total forest land area owned and forest land area that landowners were interested in managing for ecosystem services based on a mail survey of family forest owners in Mississippi conducted in 2012.

\begin{tabular}{|c|c|c|c|c|}
\hline \multirow[t]{2}{*}{ Forest type } & \multicolumn{2}{|c|}{$\begin{array}{l}\text { Forest land area } \\
\text { owned (ha) }\end{array}$} & \multicolumn{2}{|c|}{$\begin{array}{l}\text { Forest land area that landowners } \\
\text { were interested in managing for } \\
\text { ecosystem services (ha) }\end{array}$} \\
\hline & Mean & SD & Mean & SD \\
\hline Pine plantations & 57.88 & 114.61 & 39.61 & 93.35 \\
\hline $\begin{array}{l}\text { Bottomland } \\
\text { hardwoods }\end{array}$ & 33.78 & 96.91 & 24.95 & 70.01 \\
\hline Natural pine & 28.09 & 83.65 & 13.69 & 30.80 \\
\hline Natural hardwoods & 28.82 & 55.83 & 17.51 & 36.75 \\
\hline $\begin{array}{l}\text { Natural mixed pine- } \\
\text { hardwood }\end{array}$ & 31.52 & 51.24 & 20.03 & 45.40 \\
\hline
\end{tabular}


Table 5. Weighted least squares (WLS) estimation of the determinants of the percentage proportion of forest land available for ecosystem services in Mississippi based of a mail survey of family forest owners conducted in 2012.

\begin{tabular}{lrrrc}
\hline Variable & B & SE & t-value & Pr $>|\mathbf{t}|$ \\
& & & & \\
& & & & \\
\hline Intercept & -2.206 & 2.033 & -1.09 & 0.284 \\
FAMINDEX & 0.526 & 0.330 & 1.59 & 0.119 \\
P.RECR & 3.511 & 0.856 & 4.10 & $0.000^{*} *$ \\
INVEST & 0.217 & 1.113 & 0.20 & 0.846 \\
LEGACY & -0.084 & 0.607 & -0.14 & 0.890 \\
FMP & -0.622 & 0.259 & -2.40 & $0.021^{*} *$ \\
PROFORG & -0.179 & 0.245 & -0.73 & 0.469 \\
ENVORG & -0.837 & 0.532 & -1.57 & 0.124 \\
AGRICORG & -0.356 & 0.329 & -1.08 & 0.286 \\
ENROL & 0.551 & 0.321 & 1.71 & $0.094^{*}$ \\
EDUCAT & 0.801 & 0.974 & 0.82 & 0.415 \\
GENDER & 0.662 & 0.493 & 1.34 & 0.187 \\
INC & 0.001 & 0.002 & 0.76 & 0.452 \\
AGE & 0.008 & 0.012 & 0.73 & 0.470 \\
P.PINE & -0.001 & 0.004 & -0.26 & 0.795 \\
BOTMLN & 0.009 & 0.005 & 1.74 & $0.089^{*}$ \\
P.NTPINE & 0.002 & 0.005 & 0.45 & 0.653 \\
P.NTMXD & 0.012 & 0.006 & 2.01 & $0.051^{*}$ \\
\hline
\end{tabular}

$* *$ Significant at $5 \%$; Significant at $10 \%$ 